ECONOMICS

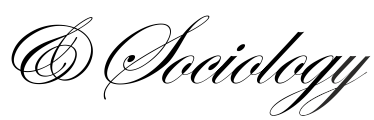

\author{
Joanna Dzialo, \\ Department of Economics, \\ Lazarski University, \\ Warsaw, Poland, \\ E-mail:jdzialo67@gmail.com
}

Bogna Gawronska-Nowak, Lazarski University,

Warsaw, Poland,

E-mail:

b.gawronska@lazarski.edu.pl

Jaroslaw Jura,

Lazarski University,

Warsaw, Poland,

E-mail:jaroslaw.jura@gmail.com

Received: January, 2017

1st Revision: March, 2017

Accepted: July, 2017

DOI: $10.14254 / 2071-$

789X.2017/10-3/9

JEL Classification: F13, F14, F53, F55, Z13
Dzialo, J., Gawronska-Nowak, B., Jura, J. (2017). Social Debate on Free Trade Agreements: Illusions Versus Reality. Economics and Sociology, 10(3), 116-135. doi:10.14254/2071-789X.2017/10-3/9

\title{
SOCIAL DEBATE ON FREE TRADE AGREEMENTS: ILLUSIONS VERSUS REALITY
}

\begin{abstract}
The paper reflects the problem of Free Trade Agreements (FTA) that recently have been raising vivid public discussion. The main focus of our study is to analyse the social debate on the FTA and to confront the social perception concerning the FTA with the socalled "expert knowledge". This may contribute both to better understanding of the controversies on the FTA and to proper indicating the possible sources of social conflicts. The results obtained seem to prove that the mismatch between social perception and expert knowledge on the FTA does exist.
\end{abstract}

Keywords: Free Trade Agreements (FTA), content analysis, social perception, policy making

\section{Introduction}

Nowadays the Free Trade Agreements (FTA-s) have been causing lots of controversies. New wave of populism, alter-globalism, and protectionism seem to be quite influential for the public discussion devoted to perspectives of implementing Transatlantic Trade and Investment Partnership (TTIP) and Comprehensive Economic and Trade Agreement (CETA). For instance, the published report (Bertelsmann Foundation, 2016) shows that there are important differences between Germans and Americans in their attitudes to trade. Only $56 \%$ of the German respondents believe increased trade relations with other countries to be something good ( $27 \%$ of the respondents are of the opposite opinion), while in America a positive opinion on the subject is shared by $82 \%$ of the respondents $(13 \%$ of the surveyed people are of the opposite opinion). According to the Eurobarometer survey (2016) a decline in support for the TTIP was reported in 14 Member States, an increase in 9, and the same sentiment in 5. Some intuitive guesses concerning the nature of the social (including this one that is Internet provided) discourse make us suspect that there are not many judgments based on merits that would be involved in it.

The main purpose of this paper is to confront the social perception concerning the FTA with the so-called "expert knowledge". Defining a mismatch between the social perception and the expert knowledge may contribute to better understanding of the 
controversies on the FTA, as well as to proper defining possible sources of social conflicts and vulnerabilities of the policy implementation level. We want to verify the following hypotheses: there is a mismatch between social perception and expert knowledge on the FTA.

The paper presents results of our research studies conducted on seven Polish web portals and one expert database. It should be mentioned that we also run the pilot survey focused on that issue (see Dzialo, Gawronska-Nowak, Jura, forthcoming). The key results of our pilot survey have been mostly confirmed in a bigger scale. We have also benefited from the pilot survey improving our methodological approach and defining sources of a possible bias in more precise way in this work.

The paper is organised as follows. Section 1 contains description of our data and some methodological remarks. Using content analysis we try to capture some mismatch between facts and social perception in section 2. We focus on the Investor-to-State Dispute Settlement (ISDS) question as a special case study in section 3. Section 4 concludes.

\section{Data description and methodological remarks}

The study presented in the paper is based on an expert base (37 documents: 20132016) and on seven Polish web portals (91988 documents, no time restriction, just subject keyword filter used:CETA, Jan 2016 - Feb 2017).

\subsection{Expert base}

The "expert knowledge" data is based on 37 documents, consisting of three basic types of publishing:

- research papers published in Polish academic journals (mostly located in the area of economics, but also social and political sciences),

- economic books,

- economic reports.

Table 1. The list of empirical research on the Free Trade Agreements used in the presented paper

\begin{tabular}{ccc}
\hline Number of documents & Years of publication & Kind of document \\
\hline 28 & $2013-2016$ & research paper \\
\hline 7 & $2012-2015$ & book \\
\hline 2 & $2015-2016$ & report \\
\hline
\end{tabular}

Source: Own elaboration based on the literature review.

Within each group of documents we select a set of sources according to the two following criteria:

- Occurrence of the key-words like: FTA, CETA, TTIP, and other phrases strictly connected with the Free Trade Agreements and combined with the words: analysis, effects, evaluation, etc.

- Names of experts who publish papers/books in the area of international trade and free trade agreements. In the process of selection of the authors, we based on our knowledge about their professionalism and high level of quality of economic debate they present, as well as on the high number of citation of their articles. 
We believe that relying on the above-mentioned criteria of selection provides us with quite complete set of the up-to-date and good quality expert level publishing on the FTA.

\subsection{Internet news websites}

The media analysis part is based on a database consisting of the content published online by Internet news portals, online versions of newspapers and independent news/opinions websites. Within each of the above-mentioned groups of data we select a set of sources according to the following criteria: significance (popularity) of the sources, possibility of publishing netizens' comments (and their frequency) and their ideological diversity (left wing, liberal, conservative, etc.). Therefore, the final choice of sources is as follows:

- Internet news portals: Onet.pl, Wp.pl, Interia.pl. They are the most popular Polish news portals (17 808 391, 14623 315, and 11802231 Internet users respectively, according to Gemius/PBI, January 2017). Content published on these portals is not strongly ideological, although onet.pl seems to be more liberal, while interia.pl a bit on the conservative side (there is no source of data nor declaration of the publisher which explicitly classifies those portals' political profile).

- Electronic versions of the Polish newspapers: Gazeta Wyborcza (GW) and Rzeczpospolita. They are the one of most popular Polish newspapers that publish articles online and enable online discussions. GW is a central-liberal newspaper, the third most popular (circa 130000 copies). It is worth to mention however that in the database we have included only those articles published in GW which were published on the gazeta.pl portal due to the fact that wyborcza.pl introduced a policy of removing opinions that are not politically correct from the publisher's point of view and therefore gather very limited number of comments. Rzeczpospolita is an example of a central-conservative media; positioned $5^{\text {th }}$ in ranking - circa 54000 copies (paid circulation data: Związek Kontroli Dystrybucji Prasy, January 2017.

- Other relevant news/opinions websites containing articles related to the CETA and allowing for publishing comments: natemat.pl, fronda.pl. Those portals are wellrecognized examples of particular ideological profiles and it was the basic criterion of selection of portals from this group. Natemat.pl is a popular liberal portal, while fronda.pl is a distinctive example of a right wing one.

Within particular source (newspaper, portal, etc.) all the obtained results (articles) of our query (using Google search machine built in on particular websites) containing keyword "CETA" are downloaded. No time restriction is imposed on query. Primarily the database consisted of 98013 records. However, due to the fact that prior to January 2016 the number of CETA related article was very low, we decided to take into consideration only those articles that were published since January 2016. Moreover, during the analysis process (qualitative part) we notice that a number of articles are not related to CETA as a FTA, but they refer to some other contexts (for example CeTA - Centrum Technik Audiowizualnych, i.e. Centre for Audio-visual Techniques, etc.). All articles and comments related to issues different from the FTA meaning are excluded from the analysis. Finally the database consists of 91998 records (91486 comments and 512 articles). The detailed distribution of documents can be seen in Table 2. 
Table 2. Social debate data base with respect to the data source and its type

\begin{tabular}{|c|c|c|c|}
\hline Number of documents (cases) & Years of publication & Kind of document & Webportal name \\
\hline 204 & $\begin{array}{c}\text { January } 2016- \\
\text { February } 2017\end{array}$ & articles & Onet \\
\hline 162 & $\begin{array}{c}\text { September } 2016- \\
\text { February } 2017\end{array}$ & articles & Interia \\
\hline 63 & $\begin{array}{c}\text { July } 2016- \\
\text { February } 2017 \\
\end{array}$ & articles & Wp \\
\hline 33 & $\begin{array}{l}\text { October } 2016- \\
\text { February } 2017\end{array}$ & articles & $\mathrm{Rp}$ \\
\hline 26 & $\begin{array}{c}\text { June } 2016- \\
\text { October } 2016\end{array}$ & articles & Fronda \\
\hline 12 & $\begin{array}{c}\text { September } 2016- \\
\text { February } 2017\end{array}$ & articles & Gazeta \\
\hline 12 & $\begin{array}{l}\text { October } 2016- \\
\text { November } 2016\end{array}$ & articles & Natemat \\
\hline 187 & $\begin{array}{c}\text { June } 2016- \\
\text { October } 2016 \\
\end{array}$ & comments & Fronda \\
\hline 69196 & $\begin{array}{c}\text { February } 2016- \\
\text { February } 2017\end{array}$ & comments & Interia \\
\hline 18654 & $\begin{array}{l}\text { January } 2016- \\
\text { February } 2017\end{array}$ & comments & Onet \\
\hline 1745 & October 2016 & comments & Gazeta \\
\hline 1478 & $\begin{array}{c}\text { September } 2016- \\
\text { February } 2017 \\
\end{array}$ & comments & $\mathrm{Wp}$ \\
\hline 137 & $\begin{array}{c}\text { October } 2016- \\
\text { November } 2016\end{array}$ & comments & Natemat \\
\hline 89 & $\begin{array}{l}\text { October } 2016- \\
\text { February } 2017\end{array}$ & comments & $\mathrm{Rp}$ \\
\hline
\end{tabular}

Source: Own elaboration based on the literature review.

Majority of data (both comments and articles) comes from Interia, Onet and Wirtualna Polska. It is related with popularity of those portals, their open access and the fact that all of them enable publishing comments in a non-censored way (for example some portals are closing down commenting possibility for certain period of time or particular thematic areas which is not a case for above mentioned portals). Although those three portals strongly influence the overall results, it shouldn't be treated as a potential bias but rather as an adequate reflection of the relevant state of play in the Polish Internet media discourse. 


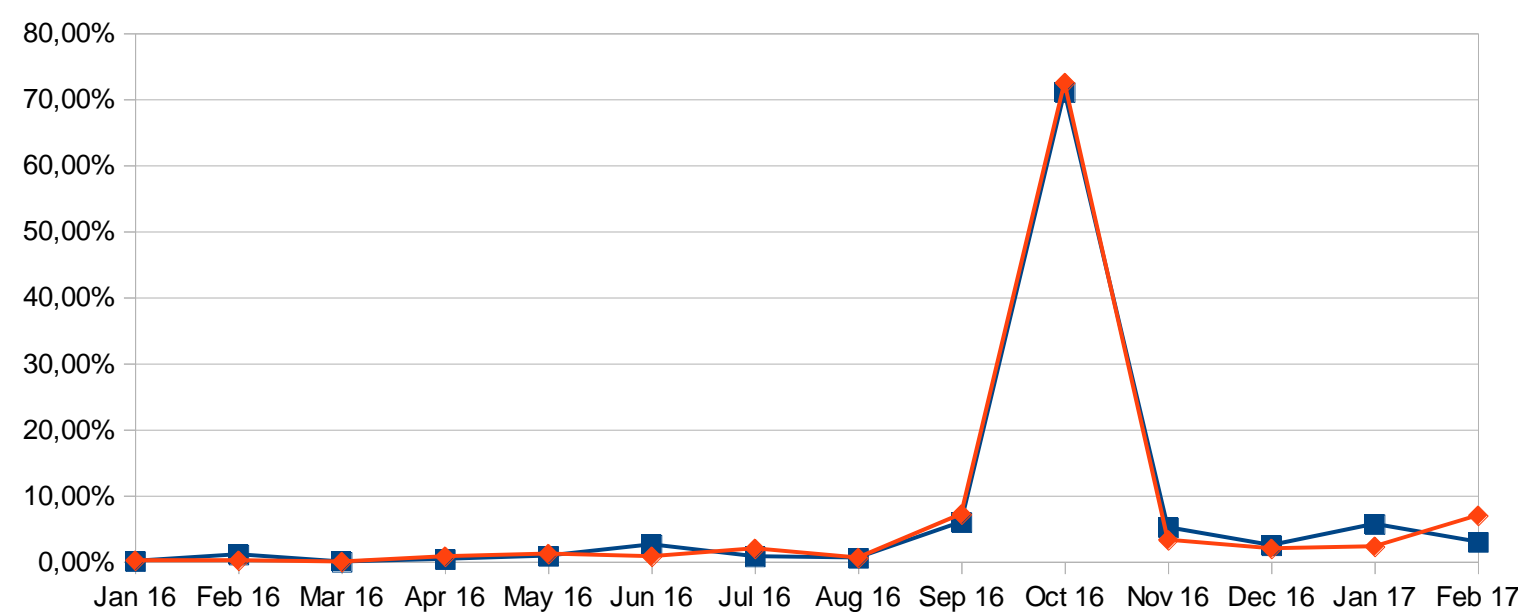

$\rightarrow$ Comments $\longrightarrow$ Articles

Figure 1. Distribution of articles and comments in time

We want to emphasize (see Figure 1) that a vast majority (more than $70 \%$ ) of the CETA related articles and discussions took place in the October 2016 (the lowest score for rp.pl both articles and comments: 55\% and 54\% respectively), when major issues related to CETA were happening (including protest against the CETA, discussion and finally signing the agreement). It suggests that both media and (consequently) netizens are interested in the CETA-related (or general - FTAs) only in case of particular spectacular events. Such events are furthermore raised by the media (often in the context of potential controversies, protests, etc.) and then they spark discussions raised by netizens. In those circumstances not much spaceis left for moreprofound discussionand,what is typical(especiallyforthe contemporary mass media),publications seem to be focusedonshort-termeffects (typically measured in the number of entries).

\subsection{Methodology - dictionary creation}

Although recently a significant development in computational linguistic resources in Poland (such as national language corpus (NKJP) and a Polish WordNet (Słowosieć) have been observed, research projects that apply automatic text classification techniques are still in the phase of development (see for example Wawer, 2012). Moreover, a relatively high level of heterogeneity of the analysed dataset, specifics of the analysed material (especially informal language of netizens' comments), application of a particular keyword (CETA) as the query keyword for search machine, and high level of complexity of Polish grammar (ibid.) make conducting a completely inductive (without any prior refinement of the text) text classification procedure such as for example unsupervised machine learning approach extremely difficult, if not - impossible (see for example Fersini, 2017; Pawar et al., 2016, etc.).

Therefore we decide to employ analytical approach based on a semi-inductively created dictionary - a keyword categorization models. The theoretical background of the dictionary creation procedure refers directly to the classical content analysis approach (see for example Krippendorff, 2004; Rifle et al., 2005) and interpretative paradigm (see for example Angen, 2000; Schutz, 1962; Garfinkel, 1967). It emphasizes the fact that researcher only interprets the text of the textual units (it means also that the objective classification method 
does not exist). Within this approach, inter-subjectivity of categorization, proposed by Holsti (1996) is crucial for the final data reliability. In our case it was secured through a discussion between researchers on newly formed categories and subsequent series of review of the dictionary.

However, due to the fact that in this particular case the classification object is a context-less keyword (not a document nor a sentence), and in order to increase the accuracy of classification method, various additional lexicometrics (KWIC, thesaurus, etc.) as well as inductive statistical methods (co-occurrence analysis) are used. In any cases where the classification is problematic, researchers check out the context of occurrence of particular keyword in order to improve classification quality. Application of the above mentioned procedure to each element of the dictionary is not possible due to the dataset size. The characteristic feature of the dictionary creation procedure is the fact that it consists of sequences of coding and recoding procedures, aimed at constant improvement of the tool.

The whole analysis is conducted with the help of QDA Miner and WordStat software.

Table 3. Data description - summary

\begin{tabular}{lll}
\hline & Expert base & Social net debate data base \\
\hline $\begin{array}{l}\text { description of the } \\
\text { sources }\end{array}$ & $\begin{array}{l}\text { results of key word googlescholar } \\
\text { and expert name based search on } \\
\text { research papers, economic books, } \\
\text { economic reports }\end{array}$ & $\begin{array}{l}\text { newspapers andindependent } \\
\text { news/opinionswebsites; contains all } \\
\text { CETArelated articles (and commentsto } \\
\text { this text) available for thesearch } \\
\text { machine; fronda, interia, netamat, } \\
\text { onet, rp, wp, gazeta }\end{array}$ \\
\hline $\begin{array}{l}\text { number of } \\
\text { documents (cases) }\end{array}$ & 37 & \multicolumn{1}{c}{91988} \\
\hline
\end{tabular}

Source: Own elaboration.

\section{Expert knowledge: Polish state-of-the-art}

The next step in our analysis is to provide a complete qualitative review of the collected set of publishing to systematize the experts' opinions on the impact of FTAs on particular areas of economic activity; additionally, social aspects were taken into consideration. The results of our review are presented in Table 4.

Table 4. Compilation of dependent variables used in the empirical research on FTAs

\begin{tabular}{ll}
\hline \multicolumn{1}{c}{ Relationship between FTAs and selected variables } & \multicolumn{1}{c}{ Author(s) } \\
\hline The impact of TTIP on selected sectors of the Polish economy & $\begin{array}{l}\text { Czarny, Dunin-Wąowicz, } \\
\text { Hagemejer, Michałek, Paliński, } \\
\text { Pawlak, Syliwoniuk, Sledziewska } \\
\text { (2016); Krzyżanowski (2016) }\end{array}$ \\
\hline Creation of new jobs in countries covered by TTIP & Kobza (2015) \\
\hline $\begin{array}{l}\text { General influence of TTIP on foreign, social and economic } \\
\text { policies of the EU and the USA }\end{array}$ & Latoszek (2014) \\
\hline $\begin{array}{l}\text { The influence of regional trade agreements on EU export and } \\
\text { import }\end{array}$ & Pera (2015), Pawlak (2014) \\
\hline $\begin{array}{l}\text { Impact of the evolution in bilateral trade agreements on the } \\
\text { exchange of goods between Poland and the other EU countries }\end{array}$ & Nacewska-Nowakowska (2015) \\
\hline
\end{tabular}


with South Korea, Peru and Colombia

Influence of the process of trade liberalization between the

European Union and some AsianCountries on the opportunities and barriers in Polish exports of agri-food

Hajdukiewicz (2016) products to selected Asian markets.

\begin{tabular}{ll}
\hline Impact of TTIP on third countries, including Australia & Kozielski (2015) \\
\hline $\begin{array}{l}\text { Changes in volume and structure of Polish trade with pork in } \\
\text { the years 2004-2013. }\end{array}$ & Czarny, Śledziewska (2015) \\
\hline
\end{tabular}

Changes in Polish foreign trade in agri-food products after joining the Single European Market and adopting the rules of

Pawlak (2015)

Common Commercial Policy of theEuropean Union.

Importance of preferential trade agreements for trade and other areas of cooperation between the EU and foreign trade partners

The impact of CETA on selected sectors of the Polish economy

Agricultural issues in the negotiations of the TIP

The problem of GMO Food Labeling in Signing of the TTIP

The benefits and risks of CETA and the consequences of the final acceptance or rejection of the agreement

The impact of Trans-Pacific Partnership on the reduction of disparities of development in the covered countries

The influence of bilateral and regional investment agreements on the volume of stock of foreign direct investment

Kawecka-Wyrzykowska (2015)

Szczepańska (2016)

Hajdukiewicz (2014)

Kaliszuk (2014)

Gostomski, Michałowski (2016);

Mazur (2014)

Legal and economic determinants of competitiveness in international trade

Gąsiorek (2016)

Liberalisation of trade with industrial goods: implications for

Poland

Słok-Wódkowsa, Śledziewska

(2014)

Conditions of access of the Polish goods to the US market in the light of TTIP

\begin{tabular}{l} 
The impact of TTIP on international cooperation \\
\hline Food safety and agriculture under the CETA regulations \\
Analysis of the costs and benefits of TTIP for the Polish \\
chemical industry
\end{tabular}

TTIP as a source of threat to the economy and society

Importance of TTIP for the European economic safety

Pluciński, Gryglik, Stosur (2016)

TTIP: threat or opportunity for the consumers and enterprises

The CETA regulations in the area of agricultural

biotechnology - reflections for TTIP

Głodowska (2015)

Impact of CETA on the trade creation effect in the case of

Poland

Influence of TTIP on the exchange rates

Pera (2015)

Przybyliński (2015)

Szczepańska (2015)

Sikora (2016)

Impact of trade agreement between the EU and Japan on

reduction of barriers of access to the Japanese goods market

and on increase in investment flow

Instruments of the food-agricultural markets' protection under FTAs

Oręziak (2016)

Szymanowski (2016)

Święcicki (2016); Dugiel (2014)

Kaliszuk (2016)

Economic relations of the EU with Asian markets: the case of

Vietnam

Ambroziak (2016)

Access to the Canadian system of public procurement under the CETA regulations

Dunin-Wąsowicz (2016)

Advantages and disadvantages of setting up of NAFTA, TTIP, and ASEAN trade agreements

Mazur (2016)

Rowiński (2013)

Błaszczuk-Zawiła (2015)

Kaliszuk (2015)

Dąbkowski (2016)

Source: Own elaboration based on the literature review. 
It is not surprising that the current debate on FTAs in Polish scientific publishing is strongly dominated by the current problems connected with CETA and TTIP. It is justified as those FTAs are a relatively new problem within the FTA area. Moreover, they concern the EU, so also Poland as a part of the EU community. If we have a look at the ranking of the most popular problems discussed within the area of CETA and TTIP, we can see that almost all the documents refer to a general problem of the impact of both CETA and TTIP on an overall economic situation of the countries involved, including GDP growth, employment and labour market conditions, international competitiveness, consumer protection, and ecological standards. A relatively small fraction of the documents refer to more narrow issues, like agricultural issues, the problem of GMO. And finally, only a few sources offer a discussion on other FTAs, like NAFTA TTP, ASEAN.

As was already mentioned, the authors focus primarily on the issues connected with the TTIP and CETA agreements. Generally they agree that establishment of TTIP and CETA may change patterns of the world's trade and capital transfers, reinforcing the Atlantic centre of the economic gravity and weakening dynamics of some Asian economies. Moreover, due to the size of such a Free Trade Area, the rules and standards adopted within them may become a point of reference for other economies and integration processes. Most authors also believe that the economic importance of those agreements, especially of the TTIP, will depend not that much on lowering of the tariffs, but on the level of decreasing the non-tariff barriers to trade (such as anti-dumping instruments, import licences, import quotas, sanitary instruments, export subsidies) mostly in the field of technical standards, but also public procurement and services. Those barriers of regulatory character have recently been the most important impediments for the EU exporters.

Each author believes that both TTIP and CETA agreements will seriously influence foreign, social and economic policies of the EU and the USA and Canada, as well as of other countries, and thus influence the global situation. However, the impact of those liberalization agreements may vary depending on the country. Although real effects of the agreements remain unknown, the authors formulate some predictions about their future impact on the economies of the countries involved. They analyse the benefits and costs of establishing TTIP and CETA in the field of trade and investment for the United States, Canada, the European Union and third countries.

In examining the impact of TTIP and CETA on economies of the countries covered, the authors refer mainly to the changes in value of trade, including the share of exports and imports, the size of average duty tariffs as well as to the non-tariff instruments. Also, they analyse possible changes in other macroeconomics indicators, predominantly in the GDP growth rate and the unemployment rate. While formulating their conclusions, the authors respond to the estimates presented in some reports, for instance those prepared by the Bertelsmann Foundation, The Centre for Economic Policy Research, and the others.

Generally, majority of the authors point to positive effects of TTIP and CETA for the economies of the countries covered. They stress that both TTIP and CETA are supposed to positively influence GDP growth and to create thousands of new jobs on both sides of the Atlantic. But, some of them formulate the opposite conclusions. They believe that the analysed FTAs carry a number of risks for the economies, the natural environment, consumer rights, labour rights and access to public services in the European Union. Especially, the ISDS mechanism poses a number of threats to democracy as well. They state that liberalization of trade within TTIP and CETA will be a factor forcing increased competition, and as a result, putting also pressure to reduce wages and other costs, including those related to the need of complying with the norms or standards. 
Comparative analysis of the Polish and foreign expert debate on the FTA (mainly CETA and TTIP) clearly points to one significant difference concerning the methodology of research. As it was presented, the current Polish debate on the FTA is based predominantly upon qualitative, descriptive analysis. There is a shortage of quantitative research, using the advanced econometric and statistical instruments. According to our knowledge, the only exception from this rule are the papers by Hagemajer (2015) and Przybylinski (2015).

On the contrary, most of foreign research is based on the computable general equilibrium models. The models have been so far used to attempt to estimate the expected effects of specific economic processes/business ventures. The models provide quite a unique possibility of a comprehensive and meaningful ex ante analysis. All the models offer the "global" perspective. The estimates make use of the GTAP (Global Trade Analysis Project) database, which contains information collected for 113 countries and 57 sectors of the economy. As to the methodological approach, the studies are either based only on CGE models or combine gravity models with CGE models. In the summary of the content of these studies, it can be concluded that macro-economic effects of FTAs (mostly TTIP) for European economies predicted on their basis are positive regardless of the variant of the proposed liberalization. Increasing the degree of liberalization strengthens their positive outcome. More detailed results, covering the data, the assumptions and the results, are shown in Table 5.

Table 5. Comparison of the results of the ex ante models

\begin{tabular}{lccccc}
\hline & Ecorys, 2009 & CEPII, 2013 & CEPR, 2013 & Bertelsmann/IFO, 2013 & $\begin{array}{c}\text { Egger } \text { et al., } \\
\text { 2015 }\end{array}$ \\
\hline $\begin{array}{l}\text { Type of the } \\
\text { model }\end{array}$ & CGE & $\begin{array}{c}\text { CGE } \\
\text { (MIRAGE) }\end{array}$ & CGE & Gravity model and CGE & $\begin{array}{c}\text { Gravity model } \\
\text { and CGE }\end{array}$ \\
\hline Data base & GTAP 7 & GTAP & GTAP 8 & Undefined & GTAP 9 \\
\hline Time & 2008-2018 & 2015-2025 & 2017-2027 & $10-20$ years & $10-20$ years \\
\hline $\begin{array}{l}\text { GDP forecast } \\
\text { for the UE }\end{array}$ & $0.35-0.72$ & $0.0-0.5$ & $0.02-0.48$ & $0.52-1.31$ & $0.1-1.14$ \\
\hline $\begin{array}{l}\text { GDP forecast } \\
\text { for the US }\end{array}$ & $0.14-0.31$ & $0.0-0.5$ & $0.01-0.39$ & $0.35-4.82$ & $0.13-0.88$ \\
\hline $\begin{array}{l}\text { UE bilateral } \\
\text { exports }\end{array}$ & Undefined & 49.0 & $0.69-28.0$ & $5.7-68.8$ & Undefined \\
\hline $\begin{array}{l}\text { Real wages in } \\
\text { the UE }\end{array}$ & $0.34-0.78$ & No data & $0.29-0.51$ & Undefined & Undefined \\
\hline $\begin{array}{l}\text { Unemployment } \\
\text { rate in the UE } \\
\text { (average) }\end{array}$ & $\begin{array}{l}\text { Unchanged } \\
\text { (assumption) }\end{array}$ & $\begin{array}{c}\text { Unchanged } \\
\text { (assumption) }\end{array}$ & $\begin{array}{c}\text { Unchanged } \\
\text { (assumption) }\end{array}$ & $\begin{array}{c}\text {-0.42(deep } \\
\text { liberalization) }\end{array}$ & $\begin{array}{c}\text { Unchanged } \\
\text { (assumption) }\end{array}$ \\
\hline
\end{tabular}

Source: Raza, Grumiller, Taylor, Tröster, Arnim, (2014); Egger, Francois, Manchin, Nelson, (2015).

Attempting to assess the quality of the debate on the FTAs run by Polish and foreign experts, it seems that "the Polish voice" in the debate sometimes may not sound convincingly enough. The Polish documents on the FTAs are much more general, of a descriptive form. Although the authors refer to some data strictly connected with trade agreements, but they do not implement an adequate set of the quantitative tools to make the use of the data more efficient. What is more, the results of the Polish research, contrary to the foreign one, are much more diversified. This is quite surprising, as one cannot find the reason for that differentiation. All the authors use almost the same or very similar data/sources of information, but formulate quite different conclusions. 


\section{Social debate versus expert knowledge}

One of crucial research goals of the paper is to clarify to what extent discussion in the media and among netizens is really focused on the FTA, and to estimate the expertise level of this discourse. In order to investigate the above mentioned issues, two major dictionaries were created: expert knowledge dictionary and common knowledge dictionary.

It is worth to mention that while conducting pilot study initial versions of above mentioned dictionaries were created and applied. Primarily the expert knowledge dictionary was based on combination of expert's self-prepared list of terms and selection of relevant keywords founded in the content of the Interia database (choice based on expert's decision). Common knowledge dictionary was constructed basing on selection of relevant keywords founded in the Interia database not included in the expert knowledge dictionary. The experience related with development of those dictionaries helped in significant way to construct and improve the final version of dictionaries described below.

The expert knowledge category is aimed at selection of the text units (comments articles, sentences, paragraphs) where more professional, merit oriented content appear. In order to secure the above-mentioned goals the following procedure is employed:

1. All the words included in the expert database with the frequency higher than 10 and all the phrases (consisting of the sequence from 2 to 6 words) with frequency equal or higher than 3 are reviewed. The base for overview and selection is the expert knowledge database.

2. All the words that (according to the coders) have possible relations with FTA-related discussions are included. There are some macroeconomic, international trade and finance terms captured that reflect mostly textbook and professional business analytical vocabulary. Names of trade and business institutions, trade agreements, trade policy tools, macro variables, macro models, trade theoretical concepts, trade legal issues were included into this set as well.

3. Stemmatisation is applied.

4. The whole dictionary is reviewed again by the main researcher (coder) and coresearches (co-coders). Finally the dictionary includes 1554 keywords and phrases(most of the keywords were stemmatized) out of the 242145 words (excluding standard WordStat exclusion list) existing in the expert database.

To create the "common knowledge" category we aim to identify all the FTA-related keywords, excluding the above described "expert knowledge" category. We are aware that in many cases these specified terms might not be used while the discussion would be still related to the FTA. Therefore we select a number of keywords, which can be associated with the FTA (in particular CETA and TTIP) thematic discussions. While creating the common knowledge dictionary the following procedure is employed:

1. All the words not included in the expert discourse dictionary with frequency higher than 10 are reviewed (in the dataset of containing media content and netizens comments).

2. All the words, which according to the coders have potential relations with the FTA, related discussions are included.

3. The decision which word could be incorporated into the dictionary is based on a preliminary co-occurrence analysis (focused on clusters where the FTA names and other FTA expert keywords have been occurring), KWIC and the researchers' knowledge about the FTA related discourse major thematic areas.

4. The dictionary is divided into several subcategories useful for our further analysis (classification to particular subcategories based on the research interest supported by the cooccurrence analysis and KWIC). The dictionary includes among others: geographical references (such as Canada, Brussels, US, etc.), words related with the negotiation process(such as to sing, negotiations, agreement, etc.), words focused on agriculture, food 
andGMO, group of words related with trade and business, different references to business units - such as corporations, concerns, enterprises, different juridical related keywords, economic jargon keywords not included into an expert dictionary, etc. (most of the above groups of keywords are divided into a distinct subcategories for example: gmo, food, business/trade, negotiations, economic jargon, geographical references, etc.).

5. Stemmatisation is applied.

6. The whole dictionary is reviewed again by the main researcher (coder) and co-researches (co-coders). It contains 671 keywords(most of the keywords are stemmatized) and phrases. The database consists of 3022096 words (excluding standard WordStatexclusion list).

While using the above dictionaries, all the documents are classified regarding to the level they are related with the FTA focused discussion.

Table 6. Article content structure with respect to its subject relation and type of netizens' knowledge

\begin{tabular}{lcc}
\hline Category & Number of cases & $\%$ \\
\hline Total & 512 & 100 \\
\hline $\begin{array}{l}\text { FTA focused (common+ expert knowledge) - occurrence of at } \\
\text { least one of expert or common knowledge category keyword }\end{array}$ & 512 & 100 \\
\hline $\begin{array}{l}\text { Expert knowledge (occurrence of expert knowledge category } \\
\text { keyword, possible occurrence of common knowledge keyword }\end{array}$ & 458 & 89.45 \\
\hline $\begin{array}{l}\text { Common knowledge (occurrence of at least one common } \\
\text { knowledge keyword, lack of occurrence of expert knowledge } \\
\text { category keyword }\end{array}$ & 54 & 10.55 \\
\hline $\begin{array}{l}\text { Unrelated with FTA (lack of occurrence of both expert nor } \\
\text { common categories keyword }\end{array}$ & 0 & 0 \\
\hline
\end{tabular}

Source: Own elaboration.

As it can be seen in Table 6,most of the articles (89.5\%) contain at least one keyword that is classified as indicator of expert level discourse (no significant differences occurs in different sources, with one exception of Fronda, where only $80 \%$ of articles contain such keywords). Moreover, all the articles contain keywords that indicate some connection with the FTA related debate (either expert of common level). It should be emphasized however that the fact that expert knowledge related vocabulary is frequently used in articles does not secure a professional, merit focused and facts based argumentation line.

On the other hand (see Table 7), 53.6\% of comments are probably not related with any FTA focused debate at all (however all of them were published in the discussion below the FTA focused articles). Only in $7.6 \%$ of comments the netizens use at least one keyword classified as an indicator of "expert knowledge". Both the above-mentioned cohorts suggest that the general level of knowledge about the problem and in-depthness of netizens interest is relatively low.

It is necessary to mention that in case of the articles there is a significant difference in the proportion of comments where at least one expert knowledge keyword appears with regards to the source. Rp.pl, fronda.pl and natemat.pl possess the highest percentage of such comments (respectively 51.7\%, 28.9\% and 24.1\%), while wp.pl gazeta.pl, onet.pl and interia.pl - the lowest (respectively $15.2 \%, 15 \%, 11.9 \%$ and $6.8 \%$. Similarly, the ratio of irrelevant comments is higher in case of interia.pl, wp.pl, fronda.pl and onet.pl $(57.6 \%$, $52.1 \%, 47.6 \%$ and $41.1 \%)$ and lower in case of gazeta.pl, natemat.pl and rp.pl $(32.8 \%, 32.1 \%$ and $31.5 \%$ ). 
Table 7. Comments content structure with respect to its subject relation and type of netizens' knowledge

\begin{tabular}{lcc}
\hline Category & Number of cases & $\%$ \\
\hline Total & 91486 & 100 \\
\hline $\begin{array}{l}\text { FTA focused (common+ expert knowledge) - occurrence of at } \\
\text { least one of expert or common knowledge category keyword }\end{array}$ & 42459 & 46.41 \\
\hline $\begin{array}{l}\text { Expert knowledge (occurrence of expert knowledge category } \\
\text { keyword, possible occurrence of common knowledge keyword }\end{array}$ & 6931 & 7.58 \\
\hline $\begin{array}{l}\text { Common knowledge (occurrence of at least one common } \\
\text { knowledge keyword, lack of occurrence of expert knowledge } \\
\text { category keyword }\end{array}$ & 35528 & 38.83 \\
\hline $\begin{array}{l}\text { Unrelated with FTA (lack of occurrence of both expert nor } \\
\text { common categories keyword }\end{array}$ & 49027 & 53.59 \\
\hline
\end{tabular}

Source: Own elaboration.

It seems that the more popular portals (with more vivid discussions) gather lowest percentage of the merit-oriented comments. On the other hand, more merit-oriented comments are published in the portals which are less popular and usually targeted at more specified audience (either more professional as rp.pl, or politically oriented - as fronda.pl and natemat.pl.

Although the tendency towards posting comments not related to the content of the article is not unusual in Internet discussions (see for ex. Halpern and Gibbs, 2013), it may also suggests that netizens either do not understand the content of articles or that it is not very interesting for them. Therefore there arises a question on how to provide information (for general public) concerning the FTA using comprehensible and catchy information formats.

Table 7. The FTA keyword co-occurrence matrix for articles and comments (within one case/document)

\begin{tabular}{|c|c|c|c|c|c|c|}
\hline \multicolumn{7}{|c|}{ Comments } \\
\hline & ACTA & CEFTA & CETA & NAFTA & TTIP & TTP \\
\hline ACTA & 407 & 0 & 240 & 5 & 127 & 6 \\
\hline CEFTA & 0 & 17 & 1 & 2 & 1 & 0 \\
\hline CETA & 240 & 1 & 10657 & 156 & 1955 & 18 \\
\hline NAFTA & 5 & 2 & 156 & 282 & 59 & 0 \\
\hline TTIP & 127 & 1 & 1955 & 59 & 2538 & 14 \\
\hline TTP & 6 & 0 & 18 & 0 & 14 & 29 \\
\hline
\end{tabular}

Source: Own elaboration.

As it may be observed in results presented in Table 7 TTIP and CETA seem to be perceived as quite similar. To an extent it is justified. They "coexist" with each other, they both refer to the EU (i.e. Poland), and they go extensively beyond a standard framework of the traditional FTA. However, we should remember that the CETA is offering quite progressive and innovative solutions to the issues that have been not sorted out in the TTIP and have resulted in some serious obstructions in the TTIP negotiation process. In particular, the Investor-to-State-Dispute-Settlement (ISDS) have been treated differently under the CETA 
umbrella. The question arises how distinctive the social perception of the FTA can be. The thematic context of the FTA focused discussion provides further insight into point of focus of the FTA related public discourse.

Table 8. The main thematic focus areas categories occurrence in FTA related articles and comments

\begin{tabular}{|c|c|c|c|c|}
\hline \multirow[t]{2}{*}{ Category } & \multicolumn{2}{|r|}{ Articles } & \multicolumn{2}{|r|}{ Comments } \\
\hline & $\begin{array}{l}\text { Number of } \\
\text { Cases }\end{array}$ & $\begin{array}{l}\% \text { (with respect to FTA } \\
\text { focused content) }\end{array}$ & $\begin{array}{l}\text { Number of } \\
\text { Cases }\end{array}$ & $\begin{array}{l}\% \text { (with respect to FTA } \\
\text { focused content) }\end{array}$ \\
\hline Agriculture & 239 & 46,68 & 4282 & 10,09 \\
\hline Corporations & 224 & 43,75 & 4674 & 11,01 \\
\hline Food & 298 & 58,20 & 7238 & 17,05 \\
\hline GMO & 153 & 29,88 & 4838 & 11,39 \\
\hline Taxes & 24 & 4,69 & 995 & 2,34 \\
\hline Trade/business & 492 & 96,09 & 13588 & 32,00 \\
\hline
\end{tabular}

Source: Own elaboration.

As we can see in Table 8 , references to any of thematic categories are significantly higher in articles than in comments. It is obviously related with the length of articles, but may also be related with the fact that articles do not focus on some specific aspect of an FTArelated area in one text. This observation shows that many articles are in a matter of fact superficial and tend to sell a catchy topic rather than to provide in-depth information (it is especially visible in case of any interviews and in articles which are a kind of short review of hottest news).

The most commonly mentioned topic in both articles and comments is trade/business (96.1\% and 32\% respectively). The least frequent is taxation system taxes. In both articles and comments, the second most commonly raised topic is related with food (58.2\% and $17.1 \%)$. It is worth to mention a relatively high position of GMO-related issues in comments (third out of six categories). It suggests that the issue of the food safety and fear related with it is quite visible in FTA focused discussion (although it has little relevance in case of CETA agreement).

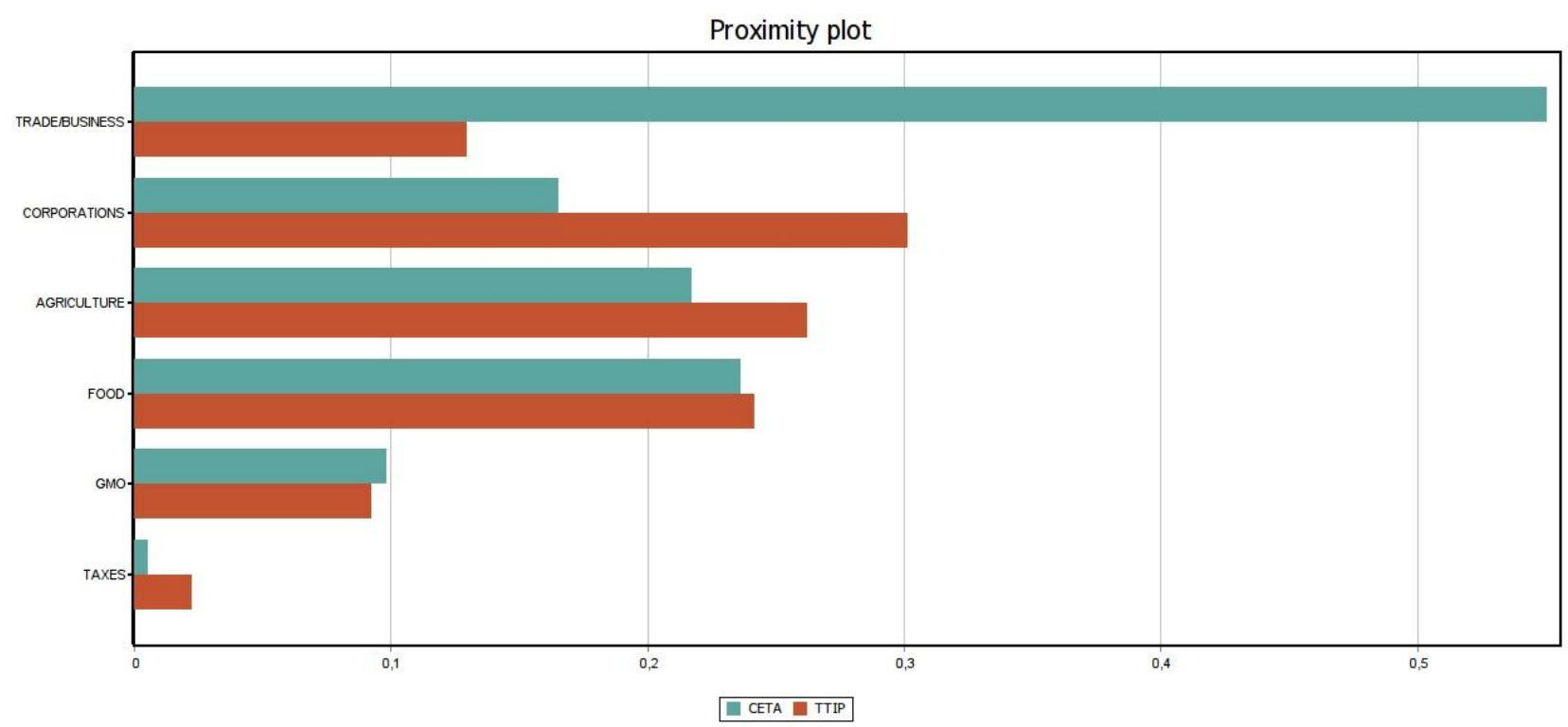


Figure 2. The CETA and the TTIP versus thematic focus areas categories in articles proximity plot (Jaccard co-occurrence coefficient within one sentence)

Comparison of the co-occurrence of CETA and TTIP keywords with thematic focus areas categories within articles provides quite a similar observation (see Figure 2). CETA and trade/business category co-occurrence seems to be dominant (with the Jaccard coefficient value higher than 0.5 , which means that number of sentences where this keyword co-occurs with any trade/business related one constitute more than $50 \%$ of all cases where at least one of them appears). "GMO" seems to possess relatively marginal position, however food and agriculture keywords co-occur quite frequently with CETA. TTIP seems to be most often associated with the "corporations" and "agriculture".

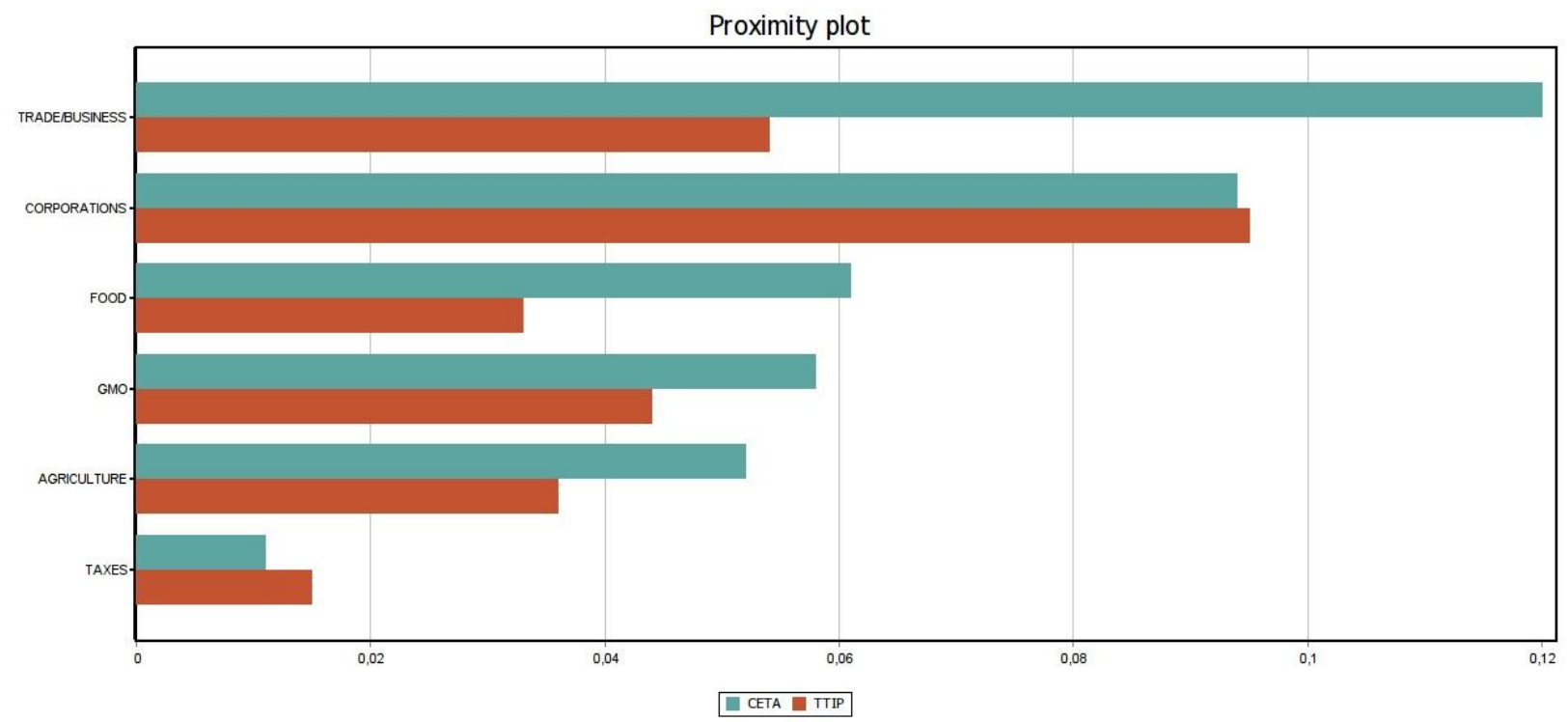

Figure 3. CETA and TTIP versus thematic focus areas categories in comments - proximity plot (Jaccard co-occurrence coefficient within one sentence)

In netizens' comments (see Figure 3) the "CETA" keyword also most frequently cooccurs with business and trade. However, a high position of corporations and relatively (comparing to the articles) high position of GMO are interesting. This observation suggests once more that a fear against food quality and increased role of corporations is present in opinions of netizens in FTA-related discussions. What is interesting, both Food and GMO cooccur more often in the case of CETA than the TTIP (where references to corporations are most important). It is quite surprising, since the problem of potential mass influx of low quality GMO food can be hardly associated with CETA (especially in final stage of negotiations). It seems that netizens have transferred directly their fears related with TTIP to CETA, without obtaining any deeper insight into the CETA text.

\section{ISDS case study}

The largest opposition against the FTA is raised by the mechanism of Investor-to-State Dispute Settlement (ISDS), which gives private investors the power to use the dispute settlement procedure in cases against foreign governments. As a result, corporations can sue governments of other countries and demand financial compensation in cases when those governments introduce new provisions, such as the protection of the environment, health or human rights, which adversely affect their financial results. This mechanism essentially grants corporations the status equal to that of governments and privatizes the dispute settlement system 
between countries. Summing up, it is said that the ISDS may be perceived as the instrument of exerting the indirect pressure on the internal policy of the host countries by the foreign investors.

Under the CETA agreement both the EU and Canada want to establish a new standard towards the investment policy, which is based on the enforcement of the Investment Court System and the State-to-State dispute settlement. It is interesting to check, if the public discourse entails these "upgrades" and if the citizens distinguish between the CETA solution and other FTA (i.e. TTIP) ISDS models.

Considering this we decide to focus on the ISDS theme in our research. All keywords (after using exclusion list and eliminating noise) with the frequency higher and equal 2 have been reviewed (in 240 sentences $^{1}$ ). Weights from 1 to 3 are defined:

$1=$ weakly related, i.e. all words associated with the ISDS in a very general and mostly implicit way (like protection, debate, democracy, etc.).

$2=$ moderately related, i.e. all words associated with the ISDS in more subject related way (mostly geographical, and institutional connotations).

$3=$ strongly related, i.e. all words associated with the ISDS in professional and tailored way (legal vocabulary, and mostly words referring to investment in economic and financial sense).

The weighs are defined on the basis of expert judgment. The stemmatisation is applied. Finally, the ISDS dictionary includes 270 keywords (most of the keywords were stemmatised) and phrases. The ISDS database consists of 242145 keywords (excluding standard WordStat exclusion list). It should be emphasized that expert panel that we run on the ISDS case study in the pilot survey did not contribute into our research results that significantly as we expected. The opinions formulated by experts were quite ambiguous. Therefore, we feel that our internal system of dictionary check is not that bias, and can be treated as a valuable substitute of the panel judgment.

Table 9 presents the results of the so-called "ISDS merit content index". The index is a weighted sum of the keyword frequencies in three categories (weakly, moderately and strongly FTA related) referred to all keywords in the subset, which can be written as follows:

$$
I S D S=\frac{1 * W R K F+2 * M R K F+3 * S R K W}{A L L}
$$

where: WRKF - weakly related keyword frequency, MRKF - moderately related keyword frequency, SRKW - strongly related keyword frequency, ALL - all keywords in the subset.

Table 9. ISDS merit index results

\begin{tabular}{lcccc}
\hline & 3 & 2 & 1 & ISDS merit index (\%) \\
\hline All sources & & & & \\
\hline comments & 415 & 205 & 158 & 45.62 \\
\hline articles & 354 & 204 & 86 & 56.36 \\
\hline Comments plus articles & 769 & 409 & 244 & 50.02 \\
\hline Interia & & & & \\
\hline comments & 246 & 118 & 65 & 46.16 \\
\hline articles & 146 & 87 & 45 & 52.06 \\
\hline Comments plus articles & 392 & 205 & 110 & 48.28 \\
\hline Onet & & & & \\
\hline comments & 150 & 79 & 86 & 43.13 \\
\hline
\end{tabular}

\footnotetext{
${ }^{1} \mathrm{~A}$ "sentence" means a set of words starting with caps letter and ending with dot.
} 


\begin{tabular}{lcccc}
\hline articles & 150 & 93 & 31 & 55.03 \\
\hline Comments plus articles & 300 & 172 & 117 & 48.25 \\
\hline
\end{tabular}

Source: Own elaboration.

The share of the ISDS merit content is not that different for articles and comments (around 50\%). That can be slightly surprising, and counterintuitive. One may expect that comments (representing "vox populi") and articles should have distinctly different shares of "merit-based" contents (intuitively comments should have lower shares of the "merit-based" contents than articles).

We try to take an inside look into the comments' content. Comments that can easily be defined as those "merit based" quite often contain professional language, are supported with some statistics/numbers and well defined case studies. They also include some references to the used data sources. Table 10 shows some examples of these types of comments.

Table 10. Examples of the selected merit-based comments

\begin{tabular}{cl}
\hline Source & Quotation (selected fragments translated from Polish into English) \\
\hline Onet & "Investors are responsible for the largest number of lawsuits in the world. Poland \\
& currently has 60 contracts with the ISDS, and is one of the states most suited to the \\
& claims of the American companies. Most of the cases pending to be proceeded by the \\
& Arbitration Court concern the tax system, environmental or health regulations or the \\
& functioning of national courts". \\
\hline Onet & "According to The Guardian, 92\% of the negotiation participants come from the \\
& corporate lobbies. Unofficially, TTIP is an attempt to achieve corporate domination \\
& over the nation. TTIP includes solutions for corporations, such as ISDS. It gives the \\
& right to sue the state by big business players (...). Such cases are to be settled by the \\
& Arbitration Court. It consists of 15 people: 5 judges from the EU, 5 from Canada and \\
& 5 from third countries". \\
"There have already been some penalties in Poland because of the claim made by the \\
Cargill company concerning restrictions on the use of isoglucose syrup. The arbitrators \\
supported the company, recognizing the restrictions as discriminatory. Penalty was \$ \\
16.3 million + interest. BIT-s (bilateral agreements) concluded with many countries, \\
and also in the USA, in the 1990s were intended to protect companies investing in non- \\
$\begin{array}{l}\text { EU countries and encourage investors. Deputy Minister of Development, Domagalski, } \\
\text { assures that Poland will introduce a Polish representative to the International Court". }\end{array}$ \\
"For example, Ecuador has been called by the Arbitration Court to pay \$ 2 billion in the \\
"Occidental" fuel business case because the state has withdrawn its oil exploration \\
concessions."
\end{tabular}

Source: Own elaboration. 
In fact, only two media sources (Onet and Interia) have covered the ISDS topic in a significant way. This observation is not sufficient, however, to prove the hypothesis that media tend to avoid discussing the crucial Free Trade Agreement subject areas profoundly.

\section{Conclusions}

1. Expert debate on the FTA is dominated by the impact of both CETA and TTIP on an overall economic situation of the countries involved, including GDP growth, employment and labour market conditions, international competitiveness, consumer protection, and ecological standards.

2. Comparative analysis of the Polish and foreign expert debate on the FTA points to a significant difference concerning the methodology of research. The current Polish debate on the FTA is based predominantly upon qualitative, descriptive analysis, while most of foreign research is based on the computable general equilibrium models, used to attempt to estimate the expected effects of the FTA.

3. A vast majority (more than 70\%) of the CETA related articles and discussions took place in the October 2016 when major issues related to the CETA occurred. It suggests that both media and (consequently) netizens are interested in the CETA-related (or general FTAs) only in case of particular spectacular events.

4. Articles and comments have different merit-based components, in favour of articles.

5. Only less than half of comments (that represent "vox populi") seems to be focused on merits, moreover the "expert" component is rather low $(\approx 8 \%)$.

6. There is a significant difference in the proportion of comments where at least one expert knowledge keyword appears with regard to the source. More popular portals (with more vivid discussions) such as wp.pl, onet.pl and interia.pl gather lowest percentage of the merit-oriented comments. On the other hand, more merit-oriented comments are published in the portals which are less popular and targeted at more specified audience (either more professional as rp.pl, or politically oriented - as fronda.pl and na temat.pl).

7. TTIP and CETA seem to be perceived as quite similar. To an extent it is justified. They "coexist" with each other, they both refer to the EU (i.e. Poland), and they go extensively beyond a standard framework of the traditional FTA. BUT...

8. CETA is offering quite progressive and innovative solutions to the issues that have been not sorted out in the TTIP and have resulted in some serious obstructions in the TTIP negotiation process. In particular, the Investor-to-State-Dispute-Settlement (ISDS) have been treated differently under the CETA umbrella. Under the CETA agreement both the EU and Canada want to establish a new standard towards the investment policy, which is based on the enforcement of the Investment Court System and the State-to-State dispute settlement. It is interesting to check, if the public discourse entails these "upgrades" and if the citizens distinguish between the CETA solution and other FTA (i.e. TTIP) ISDS models.

9. The CETA "corporations" (that contains the ISDS, as we have checked) content is very similar to the TTIP content in comments. That also refers to "taxes". That increases our doubts if the netizens realize how different both agreements are in this respect in the reality.

10. The most commonly mentioned topic in both articles and comments is trade/business, the second one is related with food. It is also worth to mention a relatively high position of GMO-related issues in comments (third out of six categories). It suggests that generally issue of food safety and some fear generating themes play quite significant role in the FTA focused discussion.

11. In netizens" comments the "CETA" keyword most frequently co-occurs with business and trade. However, a high position of corporations and relatively (comparing to the articles) 
high position of GMO are interesting. This observation suggests once more that a fear against food quality and increased role of corporations is present in opinions of netizens in FTArelated discussions. What is interesting, both food and GMO co-occur more often in the case of the CETA than the TTIP (where references to corporations are most important). It is quite surprising, since the problem of potential mass influx of low quality food (including GMO based one) can be hardly associated with the CETA (especially in final stage of negotiations). It seems that netizens have transferred directly their fears related with TTIP to CETA, without obtaining any deeper insight into the CETA text.

12. In general food, GMO, and agriculture which belong to the most popular subject areas of the public discussion seem to be treated similarly both by media as well as by netizens. This is also disappointing if to compare it with the "hard text" of the agreements (in a case of the TTIP of the proposed text). CETA grants very preferable conditions for the EU (i.e. Poland), for example establishing meat tariff-reduced-quotas on imported meat that constitute (on average) $0.2 \%$ of total EU consumption, and that refers to recognised EU standard, i.e. hormone-free-beef and rectopamie-free-pig. That has not been sorted out in the TTIP text, yet.

13. The share of the ISDS merit content is not that different for articles and comments (around 50\%). However, only two sources of media have covered the ISDS topic in a visible way. Still the open question remains if media avoid to discussing more in-depth issues?

\section{References}

Ambroziak, Ł. (2016). Efekt kreacji w handlu Polski z Kanadą po wejściu w życie umowy CETA.Unia Europejska.pl, 2, 10-28.

Angen, M. J. (2000).Evaluating interpretive inquiry: Reviewing the validity debate and opening the dialogue.Qualitative Health Research, 10, 378-395.

Błaszczuk-Zawiła, M. (2015). Stosunki gospodarcze Unii Europejskiej z krajami ASEANWietna.Unia Europejska.pl, 5, 7-17.

CETA na talerzu (2016). Raport Pulsu Biznesu.

Czarny, E., Dunin-Wąsowicz, M., Hagemajer, J., Michałek, J. J., Paliński, M., Pawlak, K., Syliwoniuk, M., Śledziewska, K. (2016). Analiza wptywu TTIP na wybrane sektory polskiej gospodarki. Wydawnictwo Scholar, Warszawa.

Czarny, E., Śledziewska, K. (2015). Polska w światowym handlu trzodą chlewną i wieprzowiną. Zeszyty Naukowe SGGW $w$ Warszawie, 15, 35-51.

Dąbkowski, A. (2016). Międzynarodowe traktaty wolnego handlu - NAFTA, TTIP, ASEAN. Zeszyty Naukowe Akademii Finansów i Biznesu Vistula, 48, 52-68.

Dugiel, W. (2015). Transatlantyckie Partnerstwo w dziedzinie Handlu i Inwestycji - wsparcie czy zagrożenie dla wielostronnych porozumień handlowych? Kwartalnik SGH Studia $i$ Prace, 1, 117-150.

Dunin-Wąsowicz, M. (2014). Umowa TTIP a kwestia walutowa. Unia Europejska.pl, 3, 6-15.

Działo, J., Gawrońska-Nowak, B., Jura, J. (2017). Social expectations concerning free trade agreements: perception versus reality. Studia Polityczne, forthcoming.

Działo, J., Gawrońska-Nowak, B. (2016). Oczekiwania wobec makroekonomicznych efektów Transatlantyckiego Partnerstwa Handlowo-Inwestycyjnego: próba konstruktywnej oceny. Myśl Ekonomiczna i Polityczna, 4, 19-54.

Działo, J., Gawrońska-Nowak, B., Stańczyk Z. (2017). Prawno-ekonomiczna analiza wybranych obszarów Transatlantyckiego Partnerstwa Handlowo-Inwestycyjnego: mity czy realne zagrożenie dla państw sygnatariuszy? Studia Prawno-Ekonomiczne, forthcoming. 
Egger, P., Francois, J., Manchin, M., Nelson, D. (2015).Non-tariff Barriers, Integration and the Transatlantic Economy.Economic Policy, 30, 34-51.

European Citizenship (2016), Standard Eurobarometer 85 Report.

Fersini, E. (2017).Sentiment Analysis in Social Networks: a Machine Learning Perspective.In: F. Pozzi, E. Fersini, E. Messina and Bing Liu (eds). Sentiment Analysis in Social Networks. Elsevier, 91-111.

Garfinkel, H. (1967).Studies in ethnomethodology.Prentice-Hall.

Gąsiorek, A. (2016). Patnerstwo Transpacyficzne - próba charakterystyki nowej megastrefy wolnego handle. International Business and Global Economy,35, 106-119.

Głodowska, A. (2016). Liberalizacja handlu towarami przemysłowymi na forum GATT/WTO. Implikacje dla Polski. International Business and Global Economy, 36, 35-57.

Gostomski, E., Michałowski, T. (2016).The benefits and risks of CETA and the consequences of the final acceptance or rejection of the agreement.Pieniadze i Więź, 19, 69-76.

Hagemejer, J. (2015).Liberalization of Trade Flows under TTIP from a Small Country Perspective. The Case of Poland.Warsaw Univeristy Working Papers, 17, 21-41.

Hajdukiewicz, A. (2016).Szanse i wyzwania rozwoju polskiego eksportu produktów rolnospożywczych na wybrane rynki azjatyckie. Studia Ekonomiczne. Zeszyty Naukowe Uniwersytetu Ekonomicznego w Katowicach, 266, 109-120.

Hajdukiewicz, A. (2014). Kwestie dotyczące rolnictwa w negocjacjach Transatlantyckiego Partnerstwa w dziedzinie Handlu i Inwestycji.International Business and Global Economy,33, 285-296.

Halpern, D., Gibbs, J. (2013). Social media as a catalyst for online deliberation? Exploring the affordances of Facebook and YouTube for political expression.Computers in Human Behavior, 29, 1159-1168.

Holsti, O. R. (1969).Content Analysis for the Social Sciences and Humanities.Addison Wesle.

Kaliszuk, E. (2014).The problem of GMO Food Labelling in Signing of the TTIP.Unia Europejska.pl, 1, 34-46.

Kaliszuk, E. (2015). Umowa CETA - dostęp do kanadyjskiego system zamówień publicznych. Unia Europejska.pl, 5, 17-29.

Kaliszuk, E. (2016). Postanowienia umowy CETA w sferze biotechnologii rolniczej wnioski dla rokowań umowy TTIP. Unia Europejska.pl, 1, 7-22.

Kawecka-Wyrzykowska, E. (2015). Preferencyjne porozumienia handlowe - znaczenie dla handlu dobrami i innych dziedzin współpracy Unii Europejskiej z partnerami zagranicznymi. Zeszyty Naukowe UE w Krakowie, 9, 5-25.

Kobza, P. (2013). Transatlantyckie Partnerstwo na rzecz Handlu i Inwestycji - nowy regionalizm atlantycki? Studia Europejskie, 3, 31-55.

Kozielski, P. (2014). Australia a Transatlantyckie Partnerstwo Handlowe i Inwestycyjne,Studia Ekonomiczne, 184, 152-167.

Krippendorff, K. (2004).Content Analysis Content Analysis An Introduction to Its Methodology. Thousand Oaks. London. New Delhi: Sage.

Krzyżanowski, J. (2016). Szanse i zagrożenia dla rolnictwa i konsumentów żywności w krajach Unii Europejskiej wynikające z ewentualnego porozumienia TTIP. Zagadnienia Ekonomiki Rolnej, 3, 3-23.

Latoszek, E., Kłos, A. (2013). Transatlantyckie Partnerstwo w dziedzinie Handlu i Inwestycji jako nowe ramy instytucjonalne współpracy gospodarczej między UE i USA. Studia Europejskie, 3, 51-71.

Mazur, G. (2016). Interesy ofensywne unijnych przedsiębiorstw w kontekście negocjowanej umowy o strefie wolego handle UE - Japonia. Unia Europejska.pl, 3, 6-18. 
Mazur, G. (2014). Kompleksowa umowa o współpracy gospodarczej i handlowej - nowy wymiar relacji Unii Europejskiej z Kanadą.Unia Europejska.pl, 6, 31-42.

Nacewska-Twardowska, A. (2015). Bilateralne rozwiązania handlowe stosowane przez Unię Europejską a wymiana towarowa Polski. Studia Ekonomiczne. Zeszyty Naukowe Uniwersytetu Ekonomicznego w Katowicach, 228, 76-91.

Oręziak, L. (2015). TTIP - Transatlantyckie Partnerstwo w sprawie Handlu i Inwestycji -źródłem zagrożeń dla gospodarki i społeczeństwa. Studia z Polityki Publicznej, 4, 81-106.

Pawar, A. B., Jawale, M. A., Kyatanavar, D. N. (2016). Fundamentals of Sentiment Analysis: Concepts and Methodology. In: Pedrycz, W., Chen, SM. (eds).Sentiment Analysis and Ontology Engineering. Studies in Computational Intelligence, 639. Springer, Cham.

Pawlak, K. (2013). Znaczenie handlu produktami rolno-żywnościowymi w wybranych regionalnych ugrupowaniach integracyjnych. Studia Ekonomiczne, 172, 141-167.

Pawlak, K. (2014). Zmiany w polskim handlu zagranicznym produktami rolno-spożywczymi po akcesji do Unii Europejskiej. Zeszyty Naukowe SGGW w Warszawie, 29, 170-184.

Pera, B. (2015). Znaczenie regionalnych porozumień handlowych Unii Europejskiej w handlu zagranicznym Polski na tle wybranych państw członkowskich. Studia Europejskie, 3, 101-119.

Pera, B. (2015). Warunki dostępu polskich towarów do rynku Stanów Zjednoczonych w kontekście Transatlantyckiego Partnerstwa Handlowo-Inwestycyjnego. Zeszyt Naukowy Wyższej Szkoły Zarządzania i Bankowości w Krakowie, 38, 71-85.

Pluciński, E. M., Gryglik, D., Stosur, A. (2016). Prawno-ekonomiczne determinanty konkurencyjności $\mathrm{w}$ handlu międzynarodowym - wybrane aspekty $\mathrm{z}$ perspektywy konkurencyjności strukturalno-czynnikowej $\mathrm{w}$ handlu Polski $\mathrm{z}$ krajami Unii Euopejskiej. Krakowskie Studia Międzynarodowe, 3, 79-104.

Przybyliński, M. (November 2015). Wptyw TTIP na Polske (analiza input-output: wstęne szacunki). Paper presented at the conference: "The Impact of the Transatlantic Trade and Investment Partnership (TTIP) on International Cooperation - Conclusions for EU Members From Central And Eastern Europe”, Warszawa 30 listopada - 1 grudnia 2015 , available

at: http://kolegia.sgh.waw.pl/pl/KGS/struktura/IMSG/konferencje/Documents/Przybylinski.pdf

Raza, W., Grumiller, W. J., Taylor, L., Tröster, B.,Arnim, R. (2014).Assessing the Claimed Benefits of the Transatlantic Trade and Investment Partnership. Policy Note, 10, 2-21.

Rowiński, J. (2013). Strefa wolnego handlu UE - USA. Instrumenty chroniące rynki rolnożywnościowe. Unia Europejska.pl, 4, 17-24.

Schutz, A. (1962).Collect Papers, Volume 1,The Hague, Martinus Nijhoff.

Sikora, A. (2016). Analiza kosztów i korzyści Polski i UE związanych z planowaną umową handlową między UE i USA (TTIP). Przemyst chemiczny, 5, 883-889.

Słok-Wódkowska, M., Śledziewska, K. (2014). Umowy inwestycyjne Unii Europejskiej i jej państw członkowskich - porównanie BIT I RTA. International Business and Global Economy,33, 36-46.

Szymanowski, R. (2015). Transatlantyckie Partnerstwo w dziedzinie Handlu i Inwestycji w kontekście europejskiego bezpieczeństwa ekonomicznego. Zeszyty Naukowe Uniwersytetu A. Mickiewicza w Poznaniu, 34, 12-31.

Święcicki, M. (2015). TTIP- zagrożenie czy szansa dla konsumentów i przedsiębiorców? Forum Ruchu Europejskiego, Sprawy Międzynarodowe, 2, 21-35.

Wawer, A. (2012).Extracting emotive patterns for languages with rich morphology.International Journal of Computational Linguistics and Applications, 3, $11-24$. 